\title{
END-OF-LIFE DECISIONS: A SURVEY OF THE PERSPECTIVES OF PEOPLE IN KOREA, CHINA, AND JAPAN
}

Ivo Kwon ${ }^{1}$, Kenji Hattori ${ }^{2}$, Kook-bong Lee ${ }^{3}$, Claire Junga Kim ${ }^{4}$

\begin{abstract}
Three East Asian countries, Korea, China, and Japan, have shared a similar cultural background throughout history. This is the basis of the assumption of Asian values in the field of bioethics. However, different processes of modernization and healthcare systems have resulted in considerable differences. Along with the aging process, end-of-life care issues have been increasing in importance in these three countries. We conducted a study of 899 lay persons in 3 countries regarding their perspectives about end-of-life decisions; favorable ways of decision-making in end-of-life care; institutional and legal devices; withdrawal of life-sustaining treatment; and euthanasia. We confirmed several similarities and noted some differences among the three countries.
\end{abstract}

Key words: end-of-life decision, advance directives, assisted dying, asian bioethics

Decisiones al final de la vida: una encuesta sobre las perspectivas de las personas en Corea, China y Japón

Resumen: Tres países del Este Asiático, Corea, China y Japón, han compartido una cultura bioética similar. Sin embargo, los procesos diferentes de modernización y los sistemas de cuidado de la salud han resultado en diferencias considerables. Junto con los procesos de envejecimiento, los temas del cuidado al final de la vida han ido creciendo en importancia en estos tres países. Realizamos un estudio con 899 personas legas en los tres países, respecto de sus perspectivas sobre decisiones al final de la vida; formas favorables de toma de decisiones en el cuidado al final de la vida; disposiciones institucionales y legales; retirada de tratamiento de sostenimiento vital; y eutanasia. Confirmamos varias similitudes y notamos algunas diferencias entre los tres países.

Palabras clave: decisiones al final de la vida, directivas anticipadas, asistencia al moribundo, bioética asiática

Decisóes de final-de-vida: uma pesquisa sobre as perspectivas da população na Coreia, China e Japáo

Resumo: Três países asiáticos, Coreia, China, e Japão, têm compartilhado uma semelhante formação cultural através da história. Esta é a base da aceitaçáo de valores asiáticos no campo da bioética. Contudo, diferentes processos de modernização e sistemas de cuidado à saúde resultaram em consideráveis diferenças. Ao logo do processo de envelhecimento, temas sobre cuidados no final-de-vida incrementaram em importância nestes três países. Nós conduzimos um estudo em 899 pessoas leigas nos 3 países considerando as suas perspectivas sobre decisões a cerca do final-de-vida; modos favoráveis de tomada de decisão em cuidados de final-de-vida; dispositivos institutionais e legais; suspensão de tratamento de sustentação da vida; e eutanasia. Nós confirmamos inúmeras semelhanças e notamos algumas diferenças entre os três países.

Palavras-chaves: decisão de final-de-vida, diretivas antecipadas, morte assistida, bioética asiática

\footnotetext{
${ }^{1}$ Department of Medical Education, School of Medicine, Ewha Womans University, Seoul, Korea

${ }^{2}$ Department of Medical Philosophy and Ethics, School of Medicine, Gunma University, Maebashi, Japan

${ }^{3}$ The School of Marxism, Shanghai Jiao Tong University, Shanghai, China

${ }^{4}$ Department of Medical Education, School of Medicine, Ewha Womans University, Seoul, Korea

Correspondence: clairejungakim@gmail.com
} 


\section{Introduction}

Korea, China, and Japan are currently experiencing aging of their societies(1), leading to an endof-life care problem. Medical practice in end-oflife care has unique problems due to the different views of people in these countries compared to those in Western societies. Advance directives or living wills are widely accepted in Western society because of the prevailing importance placed on autonomy of the individual. However, physicians in Asian countries have largely relied on the opinion of the patient's family, and have sometimes even omitted the process of notifying the patient of a precise diagnosis or identifying a patient's own wishes. There have been reports on Asian values in end-of-life decision-making, which demonstrated a Confucian worldview(2). Recognizing family members or the physician as important decision makers was interpreted as pursuing harmony and accepting the hierarchical order in a community. Nevertheless, there was also a survey that revealed ongoing westernization in medical practice in Asia(3). One should not overlook a change in values along with the rapid modernization and industrialization of society. Moreover, in medical practice in Asia, where physicians increasingly feel threatened by possible lawsuits, more and more depends on clearly defined legal documents. Therefore, it seems cru- cial to not only recognize the differences between Asian and Western societies, but to also recognize the differences among countries with the same cultural background. The present study was conducted in three Asian countries that have a shared cultural background, and showed the current picture of end-of-life care and people's perspectives on this issue.

\section{Methods}

This survey was conducted using a paper questionnaire that was originally developed by a Korean research group. Chinese and Japanese language versions of the questionnaire were provided by the Korean research team, and corrected by co-researchers in those countries. The total number of questionnaire items was 13, including 3 demographic questions. The survey protocol was approved by the Institutional Review Board of Mokdong Hospital in Seoul (Approval No. 17918). The survey was conducted from May to July 2010. A paper questionnaire form was distributed to ordinary citizens in the downtown areas of Seoul (Korea), Shanghai and Beijing (China), and Tokyo (Japan), and a street survey was conducted. Data were collected from participants who agreed to fill out the form. The collected datasets were edited, coded, and analyzed using SPSS V.12.0 (SPSS, Chicago, Illinois, USA).

Table 1. Demographic features of the respondents

\begin{tabular}{|l|c|c|c|}
\hline \multicolumn{1}{|c|}{ Criteria } & \multicolumn{1}{c|}{ Korea } & China & Japan \\
& (300 respondents) & (295 respondents) & (304 respondents) \\
\hline Gender & $154(51.3)$ & $125(42.4)$ & $151(49.7)$ \\
\hline Male & $146(48.7)$ & $170(57.6)$ & $153(50.3)$ \\
\hline Female & $90(30.0)$ & $123(41.7)$ & $79(26.0)$ \\
\hline Age groups & $100(33.3)$ & $88(29.8)$ & $86(28.3)$ \\
\hline$<35$ & $68(22.7)$ & $47(15.9)$ & $73(24.0)$ \\
\hline $35-49$ & $42(14.0)$ & $37(12.5)$ & $66(21.7)$ \\
\hline $50-65$ & \multicolumn{3}{|l}{} \\
\hline$>65$ & $49(16.3)$ & $67(23.6)$ & $11(3.9)$ \\
\hline Education level & $117(39.0)$ & $50(17.6)$ & $130(45.9)$ \\
\hline Elementary School Graduate & $134(44.7)$ & $167(58.8)$ & $142(50.2)$ \\
\hline Middle School or High School Graduate &
\end{tabular}




\section{Results}

Demographic feature of the respondents (table 1.)

The questionnaire was completed by 899 citizens. Table 1 shows the major characteristics of the respondents. There were more male than female respondents, and more older respondents in Japan than in the other two countries $(\mathrm{p}=0.000)$. In China, the proportion of people aged 20 to 34 years was $41.7 \%$, which was the largest proportion of young respondents among the three countries. There were significant differences among the three countries in terms of level of education. People with a college degree or higher constituted $58.8 \%$ of Chinese respondents, whereas only $44.7 \%$ of Korean respondents and $50.2 \%$ of Japanese respondents had this level of education. In Japan, the proportion of respondents with a lower education level than middle school was 3.9\%, which was the lowest proportion in this category among the three countries $(16.3 \%$ in Korea, $23.6 \%$ in China; $\mathrm{p}=0.000$ ).

Favorable way of receiving bad news (table 2)

We asked respondents to imagine a situation where they were in an incurable state, and death within 6 months was expected. Then we asked them the most favorable way of receiving this bad news. Respondents tended to choose the direct and frank way; $66.9 \%$ of them wanted to hear the news from a physician in a direct and frank way (Korean, 65.7\%; Chinese, 50.6\%; Japanese, $82.2 \%)$. The second most frequent answer differed among the three countries. In China and Japan, the second largest proportion of people chose to receive the news stepwise from a physician (Chinese, 22.0\%; Japanese, 7.9\%). In Korea, the second most frequent answer was direct and frank from a family member $(14.0 \%)$, and stepwise from a physician was chosen by $11.0 \%$ of Korean respondents. The difference in the answers to this question was statistically significant $(\mathrm{p}=0.000)$.

Treatment while in incurable status (table 2)

We asked the respondents, 'If you had an incurable disease such as cancer, and death was expected within 6 months, regardless of treatment, if you did not have any financial problems such as paying for treatment, how would you like to treat yourself?' The answers from the three countries varied. While over half the Korean and Chinese respondents chose aggressive medical treatment to the end (Korean, 54.0\%; Chinese, 55.3\%), only $35.3 \%$ of Japanese respondents chose the same. In contrast, $38.0 \%$ of Japanese respondents chose to prepare for death, seeking hospice treatment, compared to only $17.7 \%$ of Korean and $12.6 \%$ of Chinese respondents. This divergence seems to be partially engendered by a systematic difference. In Japan, where there are more hospice institutions than in China and Korea, respondents may be more aware of the benefits of hos-

Table 2. Preference in the situation of an irreversible condition

\begin{tabular}{|c|c|c|c|c|}
\hline & Korea & China & Japan & Total \\
\hline \multicolumn{5}{|l|}{ Favorable Way of Receiving Bad news $(\mathrm{p}=0.000)$} \\
\hline Direct and frank, from physician & $197(65.7)$ & $131(50.6)$ & $249(82.2)$ & $577(66.9)$ \\
\hline Direct and frank, from family & $42(14.0)$ & $40(15.4)$ & $11(3.6)$ & $93(10.8)$ \\
\hline Stepwise, from physician & $33(11.0)$ & $57(22.0)$ & $24(7.9)$ & $114(13.2)$ \\
\hline Stepwise, from family & $14(4.7)$ & $14(5.4)$ & $7(2.3)$ & $35(4.1)$ \\
\hline Do not want to hear & $14(4.7)$ & $17(6.6)$ & $12(4.0)$ & $43(5.0)$ \\
\hline \multicolumn{5}{|l|}{ Treatment in Incurable Status $(\mathrm{p}=0.000)$} \\
\hline Receive aggressive medical treatment to the end & $162(54.0)$ & $145(55.3)$ & $104(35.3)$ & $411(48.0)$ \\
\hline Rely on traditional medicine or folk remedy & $26(8.7)$ & $48(18.3)$ & $14(4.7)$ & $88(10.3)$ \\
\hline Prepare for death, seeking hospice care & $53(17.7)$ & $33(12.6)$ & $112(38.0)$ & $198(23.1)$ \\
\hline Depend on religion (e.g., prayer) & $20(6.7)$ & $6(2.3)$ & $0(0.0)$ & $26(3.0)$ \\
\hline Prepare for death, without any treatment & $39(13.0)$ & $30(11.5)$ & $65(22.0)$ & $134(15.6)$ \\
\hline
\end{tabular}


pice treatment, resulting in more opportunities to consider it as an option. The difference in the answer to this question was statistically significant $(\mathrm{p}=0.000)$.

Ventilator care in irreversible condition (table 3)

More respondents (69.9\% of total respondents) chose withdrawal of ventilator care rather than maintenance until cardiac death $30.1 \%$ of total respondents) when they were asked to imagine that they were in an irreversible condition and death was expected within 6 months. However, the proportion varied among the three countries: $81.5 \%$ of Japanese respondents answered that they would ask for withdrawal of the ventilator, whereas only $66.0 \%$ and $57.5 \%$ of Korean and Chinese respondents, respectively, chose the same. This difference in proportion was statistically significant $(\mathrm{p}=0.000)$. People who chose to continue ventilator care were also asked the main reason for their decision. In total, $71.6 \%$ of Korean, $56.5 \%$ of Chinese, and $23.2 \%$ of Japanese respondents said that human life is not something that can be decided by human will, but by heaven/god. This reason was the most frequent answer in Korea and China, followed by uncertainty in diagnosis of the irreversible condition (Korean 15.7\%; Chinese 18.8\%). In Japan, however, the most frequent answer was uncertainty in diagno- sis of the irreversible condition (28.6\% in Japan) together with other (28.6\% in Japan). The high proportion of the option, other, shows that further investigation is necessary with regard to Japanese respondents' reasons and their attitudes on this issue. To people who chose withdrawal, we asked a subsequent question, 'What is the main reason for that?' $42.7 \%$ of total respondents reasoned that continuing treatment for an irreversible condition was futile. This answer was most frequently chosen by Korean (59.6\%) and Chinese $(32.7 \%)$ respondents, but in Japan, the most frequent reason for withdrawal was the fact that they would be a burden to their families $(42.4 \%)$. This difference among the three countries was significant $(\mathrm{p}=0.000)$.

Decision Maker in Life-Sustaining Treatment Decisions (table 4)

The largest portion of Chinese respondents (37.6\%) answered that the patient himself/herself should be the decision maker in continuing/withdrawing life-sustaining treatment (LST) when they were asked, "Who should make medical care decisions about continuing/withdrawing ventilator care under the presumed irreversible medical condition?' However, Korean (36.3\%) and Japanese $(42.8 \%)$ respondents tended to answer, 'patient and family together,' and the proportion

Table 3. Ventilator care in irreversible condition

\begin{tabular}{|c|c|c|c|c|}
\hline Criteria & Korea & China & Japan & Total \\
\hline \multicolumn{5}{|l|}{ Ventilator Care in Irreversible Condition $(\mathrm{p}=0.000)$} \\
\hline Maintain ventilator care until cardiac death & $102(34.0)$ & $79(42.5)$ & $56(18.5)$ & $237(30.1)$ \\
\hline Ask for withdrawal of ventilator care & $198(66.0)$ & $107(57.5)$ & $246(81.5)$ & $551(69.9)$ \\
\hline \multicolumn{5}{|l|}{ Reasons for continuing ventilator care $(\mathrm{p}=0.000)$} \\
\hline Human life should be decided by heaven/god & $73(71.6)$ & $39(56.5)$ & $13(23.2)$ & $125(55.1)$ \\
\hline Uncertainty in the diagnosis of the irreversible condition & $16(15.7)$ & $13(18.8)$ & $16(28.6)$ & $45(19.8)$ \\
\hline Fear of death & $6(5.9)$ & $6(8.7)$ & $11(19.6)$ & $23(10.1)$ \\
\hline Other & $7(6.9)$ & $11(15.9)$ & $16(28.6)$ & $34(15.0)$ \\
\hline \multicolumn{5}{|l|}{ Reasons for withdrawing ventilator care $(\mathrm{p}=0.000)$} \\
\hline Futility of the treatment & $118(59.6)$ & $32(32.7)$ & $69(31.8)$ & $219(42.7)$ \\
\hline Physical/psychological pain & $31(15.7)$ & $26(26.5)$ & $26(12.0)$ & $83(16.2)$ \\
\hline Financial burden & $15(7.6)$ & $10(10.2)$ & $15(6.9)$ & $40(7.8)$ \\
\hline Burden to family & $34(17.2)$ & $29(29.6)$ & $92(42.4)$ & $155(30.2)$ \\
\hline Other & $0(0.0)$ & $1(1.0))$ & $15(6.9)$ & $16(3.1)$ \\
\hline
\end{tabular}


of respondents who answered 'patient himself' was the second largest (Korean 29.0\%, Japanese $34.5 \%)$. In China, the answer 'patient and family together' was the second largest (28.9\%).

The necessity of advance directives or living wills and favored proxy (table 4)

More than half the respondents thought that in order for patient autonomy to be respected, it is necessary for the patient to document their wishes, such as in an advance directive (AD) or living will, before he or she becomes unconscious (Korean, 73.7\%; Chinese, 65.8\%; and Japanese, $71.9 \%)$. The proportion of respondents who thought this was not necessary was $17.3 \%$ Koreans, $12.9 \%$ Chinese, and $13.6 \%$ Japanese. The rest of the respondents said they did not know. Respondents also showed a positive attitude towards the provision and governmental authorization of $\mathrm{ADs}$ or living wills $(83.0 \%$ Korean, $71.3 \%$ Chinese, and $63.7 \%$ Japanese respondents answered that it is necessary). However, the proportion was different among the three countries $(p=0.000)$. With regard to favored proxy for medical decision-making when the patient is in an unconscious state, the most favored proxy was the spouse in all three countries (Korean, 72.0\%; Chinese, 65.9\%; and Japanese 68.0\%).

Attitude towards euthanasia and withdrawal of LST (table 5)

Over half the total respondents showed a permissive attitude towards active euthanasia in cases where the patient suffers from severe pain due to an irreversible disease. In total, $68.0 \%$ of Korean, $62.7 \%$ of Chinese, and $56.3 \%$ of Japanese respondents answered that a physician can accept the request from a severely ill patient with an irreversible disease to assist death by injecting a fatal drug. However, there were statistically significant differences in the proportions, and this was also the case in the proportion of respondents who an-

Table 4. Decision maker, proxy, advance directives

\begin{tabular}{|c|c|c|c|c|}
\hline Criteria & Korea & China & Japan & Total \\
\hline \multicolumn{5}{|c|}{ Decision Maker in Life-Sustaining Treatment Decision $(\mathrm{p}=0.000)$} \\
\hline Patient himself/herself & $87(29.0)$ & $99(37.6)$ & $105(34.5)$ & $291(33.6)$ \\
\hline Patient and family member together & $109(36.3)$ & $76(28.9)$ & $130(42.8)$ & $315(36.3)$ \\
\hline Family member & $29(9.7)$ & $10(3.8)$ & $15(4.9)$ & $54(6.2)$ \\
\hline Physician & $12(4.0)$ & $9(3.4)$ & $6(2.0)$ & $27(3.1)$ \\
\hline Patient, family, and physician together & $63(21.0)$ & $69(26.2)$ & $48(15.8)$ & $180(20.8)$ \\
\hline \multicolumn{5}{|c|}{ The Necessity of Advance Directive or Living Will ( $\mathrm{p}=0.001)$} \\
\hline Necessary & $221(73.7)$ & $173(65.8)$ & $217(71.9)$ & $636(72.7)$ \\
\hline Not necessary & $52(17.3)$ & $34(12.9)$ & $41(13.6)$ & $127(14.7)$ \\
\hline Do not know & $\begin{array}{l}27 \\
(9.0) \\
\end{array}$ & $56(21.3)$ & $44(14.6)$ & $127(14.7)$ \\
\hline \multicolumn{5}{|c|}{ The Necessity of provision and governmental authorization of advance directive or living will $(\mathrm{p}=0.000)$} \\
\hline Agree & $249(83.0)$ & $194(71.3)$ & $193(63.7)$ & $611(70.6)$ \\
\hline Do not agree & $31(10.3)$ & $19(7.0)$ & $43(14.2)$ & $93(10.6)$ \\
\hline Do not know & $20(6.7)$ & $59(21.7)$ & $67(22.1)$ & $146(16.7)$ \\
\hline \multicolumn{5}{|l|}{ Favored Proxy $(\mathrm{p}=0.000)$} \\
\hline Spouse & $216(72.0)$ & $178(65.9)$ & $200(68.0)$ & $594(68.8)$ \\
\hline Children & $48(16.0)$ & $36(13.3)$ & $43(14.6)$ & $127(14.7)$ \\
\hline Physician & $19(6.3)$ & $23(8.5)$ & $22(7.5)$ & $64(7.4)$ \\
\hline Attorney & $4(1.3)$ & $23(8.5)$ & $3(1.0)$ & $30(3.5)$ \\
\hline Others & $13(4.3)$ & $10(3.7)$ & $26(8.8)$ & $49(5.7)$ \\
\hline
\end{tabular}


swered, 'I don't know' (Korean, 6.7\%; Chinese, 14.2\%; and Japanese, 25.3\%). Overall, Japanese respondents were more cautious about the issue of active euthanasia. In Japan, the smallest proportion among the three countries was permissive to active euthanasia, and the largest portion reserved judgment. On the other hand, the Japanese respondents were more supportive of withdrawing LST than respondents from the other two countries. In all, 76.3\% of Japanese respondents agreed with the idea that a physician can accept the request of withdrawing LST, whereas only $61.7 \%$ of Korean and $57.6 \%$ of Chinese respondents had the same answer. In Japan, fewer people disagreed with withdrawal $(9.2 \%)$ than in Korea (30.7\%) and China (29.5\%), and more people avoided speaking their mind in a definitive manner on this issue; $14.5 \%$ of Japanese said that they did not know compared to $7.7 \%$ in Korea and $12.9 \%$ in China. This difference was statistically significant $(\mathrm{p}=0.000)$.

Quality of life and best interest (Table 5)

More people agreed that quality of life (QoL) and a patient's best interest, rather than merely extending a patient's physical life, were more important considerations (Korean, 77.7\%; Chinese, 67.9\%; and Japanese, 80.6\%). In Japan, although the proportion of disagreement was relatively small (3.6\%) compared to that in Korea (14.7\%) and China $(10.1 \%)$, there was quite a large proportion of people who answered, 'I do not know' (Japanese, 15.8\%; Korean, 7.7\%; and Chinese, $22.0 \%)$.
Statistical Analysis based on Gender/Age/Education Factors

In terms of gender, there were few statistically significant differences in responses. However, in Korea, we observed a difference between men and women when they were asked about the favorable way of receiving bad news ( $\mathrm{p}=0.072)$. Although the most frequent answer was direct and frank from physicians from both men and women, the second most frequent answer had gender differences. Specifically, male respondents' second most frequent answer was direct and frank from family members (16.9\%), whereas female respondents chose stepwise from a physician as the second most frequent answer (15.1\%). In China, there was no difference in the first, second, and third most frequent answers between men and women. In Japan, physical/psychological pain was perceived more importantly in women than in men, when they were asked about the reason for the withdrawal of ventilator care. We asked the main reason why people would choose withdrawal of ventilator care in an irreversible condition. While only $7.1 \%$ of Japanese men chose physical/psychological pain as the reason, $17.1 \%$ of Japanese women chose the same answer and this answer ranked third, following 'burden to family' (Japanese men 39.3\%, Japanese women 45.7\%) and 'continuing treatment is futile' (Japanese men $32.1 \%$, Japanese women $31.4 \%$ ). This difference between men and women in Japan was statistically significant $(\mathrm{p}=0.003)$. In Japan, men and women also differed in their answer to the sub-

Table 5. Attitudes regarding euthanasia, withdrawal of LST, QoL

\begin{tabular}{|l|l|l|l|l|}
\hline Criteria & Korea & China & Japan & Total \\
\hline Attitude toward Euthanasia $(\mathrm{p}=0.000)$ & $204(68.0)$ & $168(62.7)$ & $171(56.3)$ & $543(62.3)$ \\
\hline Agree & $76(25.3)$ & $62(23.1)$ & $56(18.4)$ & $194(22.2)$ \\
\hline Do not agree & $20(6.7)$ & $38(14.2)$ & $77(25.3)$ & $135(15.5)$ \\
\hline Do not know & $185(61.7)$ & $156(57.6)$ & $232(76.3)$ & $573(65.5)$ \\
\hline Attitude toward withdrawal of LST (p=0.000) & $92(30.7)$ & $80(29.5)$ & $28(9.2)$ & $200(22.9)$ \\
\hline Agree & $23(7.7)$ & $35(12.9)$ & $44(14.5)$ & $102(11.7)$ \\
\hline Do not agree & \multicolumn{3}{|l|}{} \\
\hline Do not know & $233(77.7)$ & $182(67.9)$ & $245(80.6)$ & $660(75.7)$ \\
\hline Attitude toward greater importance of QoL and best interest (p=0.000) & $44(14.7)$ & $27(10.1)$ & $11(3.6)$ & $82(9.4)$ \\
\hline Agree & $23(7.7)$ & $59(22.0)$ & $48(15.8)$ & $130(14.9)$ \\
\hline Do not agree &
\end{tabular}


sequent question, 'Who should decide the continuing/withdrawal of LST?' To this question, the most frequently chosen answer among Japanese male respondents was 'patient himself/herself,' (41.3\%) followed by 'patient and family member together' (40.7\%). However, female respondents in Japan chose 'patient and family member together' (44.8\%) most frequently, and the second most frequent answer was 'patient himself/herself' (20.8\%). This difference between men and women was statistically significant $(\mathrm{p}=0.048)$. In terms of the preference of decision maker, no such differences were observed in Korea or China.

There were several differences in answers according to the different age groups. Under the assumption of an irreversible condition, when asked about ventilator care, $83.3 \%$ of Korean respondents over 65 chose withdrawal, and the proportion of respondents who gave the same response in the other age groups was approximately $60-70 \%(\mathrm{p}=0.054)$. The reason for withdrawal varied according to age. Although the main concern was 'futility of treatment' in all of the age groups in Korea, the second biggest concern varied; 'physical/psychological pain' in the younger generation, and 'burden to the family' in the older generation $(\mathrm{p}=0.085)$. With regard to ventilator care, although the youngest and oldest Chinese respondents chose withdrawal most frequent$\mathrm{ly}$, this was not statistically significant $(63.6 \%$ of those $<35 ; 55.4 \%$ of those $35-49 ; 44.1 \%$ of those $50-65$; and $63.2 \%$ of those $>65, \mathrm{p}=0.258$ ). Regarding the reason for withdrawal, different reasons from Korean respondents were noted. 'Medical futility' was not frequently chosen in the younger generation in China; however, younger respondents under 35 years were more concerned about being a burden to the family $(47.6 \%)$ and physical/psychological pain $(31.0 \%)$ than other age groups. On the other hand, the older generation was less concerned about pain $(8.3 \%)$, and their concerns distributed equally to the rest of the answers (futility $33.3 \%$, financial burden $33.3 \%$, burden to family $25.0 \%$, in those $>65$ ). In Japan, a similar tendency to Korea regarding ventilator care was observed, but it was more drastic. Older respondents in Japan tended to choose ventilator withdrawal (respondents who chose withdrawal of ventilator care were $55.1 \%$,
$89.5 \%, 93.1 \%$, and $89.4 \%$ of those aged $<35$, 35-49, 50-65, and over 65, respectively). This difference among the Japanese age groups was statistically significant $(\mathrm{p}=0.000)$. The reason for withdrawal of ventilator care also varied among different age groups in Japan. While older people were more concerned about the futility of treatment in an irreversible condition (respondents who chose the corresponding answer were $21.6 \%$ of those $<35,20.0 \%$ of those $35-49,33.3 \%$ of those $50-65$, and $54.0 \%$ of those $>65$ ), younger people tended to be more concerned about the burden placed on family $(45.9 \%, 51.4 \%, 40.0 \%$, and $30.0 \%$ of those $<35,35-49,50-65$, and $>65$, respectively). This difference in Japan was statistically significant $(\mathrm{p}=0.015)$.

Respondents showed several differences according to their education level, which was classified into two groups: college graduates (CGs) and non-college graduates (NCGs). In Korea, the most favorable way of receiving bad news was direct and frank from a physician, regardless of education level, but the proportion differed according to education level $(57.8 \%$ of NCGs, $75.4 \%$ of CGs, $\mathrm{p}=0.023)$. In response to the same question, Chinese respondents chose direct and frank from a physician in both groups (NCGs, 55.2\%) (CGs, 47.4\%), but the second most frequent answer varied. For CGs, it was direct and frank from a family member (27.9\%), but for NCGs, it was stepwise from a physician (21.9\%). In Japan, most respondents tended to choose direct and frank from a physician, regardless of education level, and the difference between the education levels was not significant $(\mathrm{p}=0.366)$. In terms of ventilator care in an irreversible condition, Korean respondents preferred withdrawal of ventilator care regardless of education level $(65.7 \%$ of NCGs, $66.4 \%$ of CGs, $\mathrm{p}=0.891$ ). Chinese CGs tended to choose withdrawal of ventilator care (63.1\%), whereas the NCGs were divided almost equally into two groups; $50.7 \%$ chose continuing medical care and $49.3 \%$ chose withdrawing ventilator care; $\mathrm{p}=0.063$ ). NCGs in Japan were more prone to choosing withdrawal of ventilator care in an irreversible condition than CGs $(91.5 \%$ of NCGs, $70.7 \%$ of CGs; $\mathrm{p}=0.000$ ). 


\section{Discussion}

Contrary to medical practice based on the presumption about the negative psychological effects on patients(4-6), the present study of healthy citizens showed that over half of the citizens from the three Asian countries want to know their health condition and prognosis from their doctor in a direct and frank way. This finding is in accordance with other studies from East Asian countries(7-9). As Chen et al.(3) noted, the form of East Asian medical encounters has changed a lot; therefore, only communicating with the patient's family, without the patient himself, is too simplistic an approach. This trend was also apparent in answers about the desired decision maker on LST. The most frequent answer, 'patient and family member together' was followed by 'patient himself/herself' with only a very small gap between them $(2.7 \%)$. In the study by Kwon et al.(10), terminally ill patients in East-Asian countries also showed a willingness to decide their own treatment. This shows that East Asian people assign an important role to their families, although a considerable proportion of them do not leave everything about end-of-life decision making to their families.

Favorable treatment options in an incurable state seem to be determined by the healthcare system. In mapping the level of palliative care in the world's 234 countries, Lynch et al.(11) categorized Japan into advanced integration, which is the top among six categories, China into preliminary integration, which is second among the six categories, and Korea into isolated provision, which is third among the six categories. Japanese respondents tended to refrain from aggressive medical treatment such as ventilator care in an incurable state, and preferred to prepare for death by seeking hospice care, which may be due to the well-developed hospice care system that the country has built since the 1970 's $(12,13)$.

The reasons for or against ventilator care in an irreversible condition are worth mentioning. In consideration of withdrawal or continuance, the most frequent answer was futility and god/heaven's authority, respectively. Although these two answers were acquired from respondents with opposing choices (withdrawal/continuance), it seems that both reflect the East Asian traditional view of death. The three traditional East Asian philosophies, namely Confucianism, Buddhism, and Taoism, do not pay much attention to the afterlife. Rather, they all emphasize the need to stay detached from the subject of death and abstain from being obsessed with the fear of death(14). Acceptance of death as a natural phenomenon is common in the three different viewpoints. Because the notion of futility is much more complex and can be interpreted in various ways, especially by lay people, it is plausible to assume that respondents understood the concept, futility as an obsession with life and rejection of the natural pathway or dao. This is in accordance with the reference of heaven/god's will in continuing the treatment. To summarize, people showed a willingness to follow the way of nature/heaven's will in end-of-life decisions. This is quite a different approach to that regarding a patient's autonomy or quality of life.

People were positive about the means that allow them to determine their own decisions about end-of-life treatment. The preference for self-determination conflicts with the current practice in Asia. ADs are now in the stage of introduction, as reflected in the guidelines from the 'Special Committee in National Bioethics Committee' in Korea (15). Although $58.4 \%$ of nursing homes in Japan adopted ADs, only 39.9\% offered the AD form with which a patient can specifically select their choice of treatment(16). In mainland China, palliative care is developing slowly, and there is currently no case law regarding $\mathrm{AD}$. In mid 2013, the Beijing Advance Directive Promotion Association was established with the approval of the Beijing Civil Affairs Bureau. Charged by the Beijing Ministry of Health, this organization aims to promote the uptake of ADs in China, inform Chinese people of their rights to prospectively define their end-of-life care preferences, and enhance care of the dying(17). Without exact documents on a patient's own will, practitioners rely on Do-not-Resuscitate(DNR) orders from a patient's family when they deal with $\operatorname{LST}(18,19)$. This topic is particularly problematic, considering that people in East Asia rarely mention their own death or their preferences for end-of-life care(20). Data from this research supports the 
need for implementation of means such as ADs that guarantee respect for patient autonomy in East Asian countries.

What is interesting is that Japanese respondents agreed on the necessity of ADs, but showed a lukewarm attitude to governmental authorization on ADs. Previous studies have assumed that Japanese people were concerned with the potential risk of excessive withdrawal of treatment following the acceptance of $\mathrm{ADs}$, considering the context of national health insurance (NHI), which covers most medical expenses $(16,21)$. This potential problem of excessive pressure to withdraw treatment is also the case in Korea, where national healthcare insurance covers at least part of the medical expenses of every citizen and death-related expenses constitute $8.3 \%$ of the total NHI expenditure(22).

People were permissive to both active euthanasia and withdrawal of LST. However, they did not seem to grasp the different significance of the two actions. For example, people were more permissive to active euthanasia than withdrawal of LST in Korea and China. In Japan, where the history of discussion of end-of-life treatment is longer than in the other countries, respondents were more supportive of withdrawal of LST than active euthanasia. This shows that people in Japan discern the moral significance of the two different actions more clearly, or at least concordantly with the general consensus in current biomedical ethics. In Japan, with a different definition of euthanasia from the West, several euthanasia cases were dealt with in court, and all of the defendants were found guilty. However, withdrawal of LST in irreversible conditions is permissible in Japan, because the physician has no duty to continue futile treatment in those cases(23). With prior court cases in Japan, people seem to acknowledge the difference between the two acts.

This study had several limitations. First, the surveys were conducted in downtown metropolitan cities, and the results may not fully reflect the thoughts of the whole population of the three countries. This is especially relevant in China, which has a huge territory. Second, the lack of standardization of age, education, and other demographic profiles was another limitation. Be- cause the data were collected from a street survey, the precise response rate could not be calculated and some respondents might have completed the survey without much serious consideration.

Despite these limitations, this study indicates what people who live in the East Asian region think of end-of-life treatment. With the aging of these societies, people deem end-of-life treatment, especially aggressive treatment in a hospital, as something that should be chosen according to their own wishes, rather than something that is mandatory or solely decided by family members or physicians. The study also reveals that it is risky to adopt a simplistic approach based on the belief in a single East-Asian view. There were several points of similarity, but there were also different answers due to different healthcare systems and social structures. The traditional perspective, including Confucianism, captures what people think to a certain degree, but self-determination based on autonomy is also important, due to social change and westernization. Moreover, it is expected that these three countries will hold public discussions about end-of-life care and undertake reformation of health care, considering the permissive attitude on several issues, which have also been the subject of much debate in Western countries.

\section{Funding}

This study was supported by the Korean Research Foundation Grant, funded by the Korean Government (Ministry of Education and Human Resources Development (MOEHRD), Basic Research Promotion Fund) (KRF-2008321-A-00024).

\section{Conflicts Of Interest}

None

\section{Ethics approval}

Ethics approval was provided by Ewha Womans University Mokdong Hospital (Approval No 179-18). 
End-of-Life decisions - Ivo Kwon, Kenji Hattori, Kook-bong Lee, Claire Junga Kim

\section{References}

1. World Health Organization. Active Ageing; A Policy Framework. Available at: http://whqlibdoc.who.int/hq/2002/ WHO_NMH_NPH_02.8.pdf

2. Fan R. Self-Determination vs. Family-Determination: Two Incommensurable Principles of Autonomy. Bioethics 1997; 11(3-4); 309-322.

3. Chen YY, Tsai SL., Yang CW, Ni YH, Chang SC. The Ongoing Westernization of East Asian Biomedical Ethics in Taiwan. Social Science \& Medicine 2013; 78: 125-129.

4. Gabbay BB, et al. Negotiating End-of-Life Decision Making: A Comparison of Japanese and U.S. Residents' Approaches. Academic Medicine 2005; 80(7): 617-621.

5. Mobeireek AF, et al. Information Disclosure and Decision-Making: the Middle East versus the Far East and the West. Journal of Medical Ethics 2008; 34(4): 225-229.

6. Searight, HR, Gafford J. Cultural Diversity at the End of Life: Issues and Guidelines for Family Physicians. American Family Physician 2005; 71(3): 515-522.

7. Akabayashi A, Fetters MD, Elwyn TS. Family Consent, Communication, and Advance Directives for Cancer Disclosure: A Japanese Case and Discussion. Journal of Medical Ethics 1999; 25(4): 296-301.

8. Kao CY, Cheng SY, Chiu TY, Chen CY, Hu WY. Does the Awareness of Terminal Illness Influence Cancer Patients' Psycho-Spiritual State, and Their DNR Signing: A Survey in Taiwan. Japanese Journal of Clinical Oncology 2013; 43(9): 910-916.

9. Wang SY, Chen CH, Chen YS, Huang HL. The Attitude Toward Truth Telling of Cancer in Taiwan. Journal of Psychosomatic Research 2004; 57(1): 53-58.

10. Ivo, K et al. A Survey of the Perspectives of Patients Who are Seriously Ill Regarding End-of-Life Decisions in Some Medical Institutions of Korea, China and Japan. Journal of Medical Ethics 2012; 38(5): 310-316

11. Lynch T, Connor S, Clark D. Mapping Levels of Palliative Care Development: A Global Update. Journal of Pain and Symptom Management 2013; 45(6): 1094-1106.

12. Miyashita M, Morita T, Tsuneto S, Sato K, Shima Y. The Japan Hospice and Palliative Care Evaluation Study (J-HOPE study): Study Design and Characteristics of Participating Institutions. American Journal of Hospice and Palliative Medicine 2008; 25(3): 223-232.

13. Choi J, et al. Preference of Place for End-of-Life Cancer Care and Death among Bereaved Japanese Families who Experienced Home Hospice Care and Death of a Loved One. Supportive Care in Cancer 2010; 18(11): 1445-1453.

14. Kwon I. Koreans' Traditional View on Death. Korean Journal of Palliative Care 2013; 16(3): 155-165.

15. Special Committee in National Bioethics Committee. Recommendation for Decision Making in Futile End-of-Life Care. 2013/5/21

16. Takezako Y, Ishikawa S, Kajii E. Advance Directives in Japanese Nursing Homes. Journal of Pain Symptom Management 2013; 45(1): 63-70 e67.

17. Ni P, Zhou J, Wang ZX, Nie R, Phillips J, Mao J. Advance Directive and End-of-Life Care Preferences Among Nursing Home Residents in Wuhan, China: A Cross-Sectional Study. Journal of the American Directors Association 2014; 15(10): 751-756

18. Liu JM, et al. The status of the Do-not-Resuscitate Order in Chinese Clinical Trial Patients in a Cancer Centre. Journal of Medical Ethics 1999; 25(4): 309-314.

19. Lee TR, et al. A Survey of Residents' Views of DNAR Orders in One University Hospital. Korean Journal of Medical Ethics; 14(3): 276-284.

20. Chou WC, et al. Impact of Palliative Care Consultative Service on Disease Awareness for Patients with Terminal Cancer. Support Care in Cancer 2013; 21(7): 1973-1981.

21. Ito M. Health Insurance Systems in Japan: a Neurosurgeon's View. Neurologia medico-chirurgica 2014; 44(12): 617-628.

22. Shin HC, Choi MY, Tchoe BH. The Cost of End-of-Life Care in South Korea. Korean Journal of Health Policy and Administration 2012; 22(1): 29-48.

23. Hirano M. Issues in Euthanasia Jurisprudence in Japan. Biomedical Law \& Ethics 2011; 5(2): 21-46.

Received: March 19, 2015

Accepted: March 28, 2015 